\title{
KERAGAMAN KONSUMSI PANGAN RUMAH TANGGA DI PROVINSI JAWA TENGAH
}

\section{DIVERSITY OF HOUSEHOLD FOOD CONSUMPTION IN CENTRAL JAVA PROVINCE}

\author{
${ }^{*}$ Sukmasari Dewanti \\ Mahasiswa Program Studi S2 Kependudukan Universitas Gadjah Mada \\ ${ }^{2}$ R. Rijanta dan Abdur Rofi ${ }^{3}$ \\ Fakultas Geografi Universitas Gadjah Mada
}

Submitted: 19-06-2019; Revised: 25-07-2020; Accepted:25-07-2020

\begin{abstract}
Central Java Province is one of the provinces with good food availability marked by its contribution as one of the national food barns that produces various types of food, such as rice, corn, cassava, peanuts, soybeans, and green beans. However, this does not necessarily make this province free from food problems. One of the food problems faced by Central Java Province is calorie consumption which is still below the national figure in 2017 and consumption of food that is not varied. Food consumption that is too dependent on certain types of food may disrupt the stability of food security. This study aims to analyze the diversity of food consumption, variations in the diversity of food consumption between the residency areas; demographic and economic social factors that affect the diversity of household food consumption; and analyze the relationship between the level of diversity of food consumption with the level of food security in Central Java Province. This research uses the data from the National Social-Economy Survey of March 2018, which is analyzed with the descriptive analysis and inferential analysis using binary logistic regression. The result shows that variety in food concumption in 2018 Central Java is good conditions, as reflected in the score of Desirable Dietary Pattern (DDP) that reaches 89,07 . The consumption of cereal group and added fats \& oils group has exceeded ideal conditions. Besides, there is a variation in the diversity of food consumption in the six residency areas in Central Java. Binary logistic regression analysis concluded that gender, age, education level of the head of the household, number of household members, residence status, and household income per capita affected the diversity of food consumption. The diversity of food consumption and household food security has been shown to have a positive and significant relationship.
\end{abstract}

Keywords: Diversity Food Consumption; Desirable Dietary Pattern; Food Security; Logistic Regression; Economic Social Demographic Factors.

${ }^{*}$ Corresponding author: sde.sukma@gmail.com.

Copyright@ 2020 THE AUTHOR (S). This article is distributed under a Creative Commons Attribution-Share Alike 4.0 International license. Jurnal Kawistara is published by the Graduate School of Universitas Gadjah Mada. 


\section{ABSTRAK}

Provinsi Jawa Tengah adalah salah satu provinsi dengan ketersediaan pangan yang cukup baik ditandai dengan kontribusinya sebagai salah satu lumbung pangan nasional yang menghasilkan berbagai jenis pangan, seperti padi, jagung, ubi kayu, kacang tanah, kedelai, dan kacang hijau. Meskipun demikian, hal itu tidak membuat provinsi ini terbebas dari persoalan pangan. Salah satu persoalan pangan yang dihadapi Provinsi Jawa Tengah adalah konsumsi kalori yang masih di bawah angka nasional pada tahun 2017 dan konsumsi pangan yang belum beragam. Konsumsi pangan yang terlalu bertumpu pada jenis pangan tertentu dikhawatirkan akan mengganggu stabilitas ketahanan pangan. Penelitian ini bertujuan untuk menganalisis keragaman konsumsi pangan, variasi keragaman konsumsi pangan antar wilayah ekskeresidenan; faktor sosial demografi dan ekonomi yang memengaruhi keragaman konsumsi pangan rumah tangga; serta menganalisis hubungan tingkat keragaman konsumsi pangan dengan tingkat ketahanan pangan di Provinsi Jawa Tengah. Penelitian ini menggunakan data bersumber dari Survei Sosial Ekonomi Nasional (Susenas) Maret 2018 yang dianalisis menggunakan analisis deskriptif dan analisis inferensia menggunakan regresi logistik biner. Hasil penelitian menunjukkan bahwa kondisi keragaman konsumsi pangan di Provinsi Jawa Tengah tahun 2018 sudah cukup baik yang tercermin dari skor pola pangan harapan mencapai 89,07 . Konsumsi padi-padian dan minyak \& lemak sudah melebihi kondisi ideal. Selain itu, terdapat vasiasi keragaman konsumsi pangan pada keenam wilayah ekskeresidenan di Jawa Tengah. Analisis regresi logistik biner menyimpulkan jenis kelamin, umur, tingkat pendidikan kepala rumah tangga, jumlah anggota rumah tangga, status daerah tempat tinggal dan pendapatan perkapita rumah tangga memengaruhi keragaman konsumsi pangan. Keragaman konsumsi pangan dan ketahanan pangan rumah tangga terbukti memiliki hubungan positif dan signifikan.

Kata kunci: Keragaman Konsumsi Pangan; Pola Pangan Harapan; Ketahanan Pangan; Regresi Logistik; Faktor Sosial Demografi Ekonomi.

\section{PENGANTAR}

Keragaman konsumsi pangan di negara berkembang cenderung masih rendah. Makanan sumber karbohidrat, terutama kelompok padi-padian menjadi penyumbang utama energi untuk makanan yang dikonsumsi oleh rumah tangga dibandingkan dengan kelompok makanan lainnya. Ruel (2003b) dan Mekuria, Wubneh, dan Tewabe (2017) dalam penelitiannya menyebutkan bahwa penduduk di negara berkembang, terutama pada kelompok penduduk miskin cenderung lebih banyak mengonsumsi kelompok pangan yang mengandung tepung, seperti beras, gandum, jagung dan kurang mengonsumsi produk hewani, buah-buahan, dan sayuran segar. Konsumsi makanan yang tidak diimbangi dengan kecukupan asupan sayuran, buah, biji-bijian utuh, dan sumber pangan hewani memiliki konsekuensi berupa densitas makronutrien dan mikronutrien rendah dan ketersediaan biologis mineral yang rendah dan akan mengakibatkan gangguan pertumbuhan, perkembangan, dan pertahanan terhadap infeksi (Michaelsen dkk, 2009).

Keragaman konsumsi pangan merupakan upaya untuk mewujudkan kecukupan nutrisi yang dibutuhkan tubuh. Hal ini didasarkan pada fakta bahwa tidak ada tidak ada makanan tunggal apapun yang mengandung semua nutrisi yang dibutuhkan tubuh (Suryana, 2008). Semakin banyak kelompok makanan yang dikonsumsi sehari-hari, maka semakin besar peluang nutrisi tubuh dapat tercukupi (Labadarios, Steyn, dan Nel, 2011). Oleh karena itu, penganekaragaman konsumsi pangan perlu dilakukan untuk meminimalkan risiko defisiensi nutrisi tertentu akibat konsumsi yang bertumpu hanya pada bahan pangan tertentu. Konsumsi pangan yang beragam dan bergizi seimbang terbukti berdampak positif terhadap peningkatan kualitas hidup Sumber Daya Manusia (SDM) (Parappurathu dkk, 2015; Hamid, Setiawan, dan Suhartini, 2013; Suryana, 2008).

Jika dihubungkan dengan tingkat ketahanan pangan, keragaman konsumsi pangan berkontribusi menopang pilar ketahanan pangan (Hoddinott dan Yohannes, 2002; Ruel, 2003; Parappurathu dkk, 2015). Ismiasih (2014) menyimpulkan dalam penelitiannya bahwa tingkat diversifikasi atau penganekaragaman konsumsi pangan dapat meningkatkan peluang rumah tangga untuk semakin tahan pangan. Konsumsi energi dari berbagai macam jenis 
pangan menjadikan konsumsi tidak hanya terfokus pada kelompok pangan tertentu saja, tetapi menjadi semakin beragam alternatif jenis pangan yang dapat dikonsumsi. Oleh karena itu, konsumsi pangan yang beragam menjadi hal yang penting untuk dilakukan. Adapun indikator untuk mengukur keragaman konsumsi pangan adalah Pola Pangan Harapan (PPH).

Berdasarkan Badan Ketahanan Pangan (2018), keragaman konsumsi pangan penduduk Provinsi Jawa Tengah dilihat dari capaian skor PPH selama periode 2013-2017 masih belum memuaskan, di mana skor yang dicapai belum mencapai skor ideal nya yaitu 100. Selain itu, skor PPH Jawa Tengah selama kurun waktu tersebut selalu berada di bawah skor PPH nasional. Jika dibandingkan dengan dua provinsi tetangganya, capaian skor $\mathrm{PPH}$ pada tahun 2017 juga masih berada di bawahnya, yaitu DI Yogyakarta (skor PPH 89,0) dan Jawa Timur (skor PPH 89,7). Padahal, jika ditinjau dari ketersediaan pangannya, Provinsi Jawa Tengah merupakan salah satu wilayah lumbung pangan nasional yang menghasilkan berbagai jenis pangan. Selain itu, jika ditinjau dari aspek ketahanan wilayahnya, Provinsi Jawa Tengah merupakan provinsi teridentifikasi sebagai wilayah tahan pangan (Dewan Ketahanan Pangan, Kementerian Pertanian, dan World Food Programme, 2015). Oleh karena itu, kondisi keragaman pangan di Provinsi Jawa Tengah menarik untuk diteliti.

Tujuan tulisan ini untuk melihat sejauhmana capaian keragaman konsumsi pangan di Provinsi Jawa Tengah dengan menggunakan pendekatan Pola Pangan Harapan (PPH) pada tahun 2018; variasi keragaman konsumsi pangan antarwilayah ekskeresidenan di Provinsi Jawa Tengah; faktor sosial demografi dan ekonomi yang memengaruhi keragaman konsumsi pangan tingkat rumah tangga; serta apakah terdapat hubungan antara keragaman konsumsi dengan ketahanan pangan tingkat rumah tangga di Provinsi Jawa Tengah.

Keragaman konsumsi pangan dipengaruhi oleh banyak faktor, seperti karakteristik rumah tangga. Penelitian yang dilakukan oleh Parappurathu dkk (2015) di India Timur,
Workicho dkk (2016), Misker, Misker, dan Ayele (2016), dan Mekuria dkk (2017) di Ethiopia, serta Codjoe, Okutu, dan Abu (2016) di Ghana mengungkapkan bahwa jenis kelamin kepala rumah tangga memiliki hubungan yang nyata dalam memengaruhi keragaman pangan rumah tangga. Rumah tangga yang memiliki kepala rumah tangga laki-laki cenderung memiliki keragaman konsumsi pangan yang lebih tinggi dibandingkan dengan rumah tangga dengan kepala rumah tangga perempuan.

Telah banyak penelitian yang menunjukkan bahwa pendidikan kepala rumah tangga memiliki pengaruh signifikan dan positif dalam menentukan keragaman pangan (Hanafi, Asmara, dan Nugroho, 2008; Taruvinga dkk, 2013; Surachman, Kusrini, dan Suyatno, 2013; Parappurathu dkk, 2015; Codjoe, dkk, 2016). Semakin tinggi pendidikan kepala rumah tangga, maka keragaman pangan rumah tangga tersebut juga turut meningkat.

Penelitian yang dilakukan Asmara dkk (2009); Surachman, Kusrini, dan Suyatno (2013); Ismiasih dkk (2013) mendapati bahwa jumlah anggota rumah tangga berpengaruh signifikan terhadap keragaman konsumsi pangan (energi) dengan arah hubungannya bersifat negatif. Artinya bahwa semakin banyak jumlah anggota rumah tangga yang ada dalam suatu rumah tangga, maka semakin rendah tingkat keragaman konsumsi pangan rumah tangga tersebut.

Daerah tempat tinggal merupakan faktor yang memengaruhi akses rumah tangga terhadap pangan yang beragam. Penelitian Hamid, dkk (2013); Workicho dkk (2016) menemukan bahwa daerah tempat tinggal berpengaruh nyata terhadap tingkat keragaman konsumsi pangan. Rumah tangga yang tinggal di wilayah perkotaan cenderung memiliki tingkat keragaman konsumsi pangan yang lebih tinggi daripada rumah tangga perdesaan.

Pendapatan merupakan salah satu faktor penting yang turut mendorong terjadinya pergeseran pola konsumsi. Pola konsumsi cenderung mengarah pada konsumsi pangan yang lebih beragam ketika terjadi peningkatan pendapatan. Hal tersebut terkait dengan peningkatan daya beli seseorang, sehingga 
orang tersebut cenderung memiliki kesempatan yang lebih banyak dibandingkan dengan orang pada tingkat pendapatan di bawahnya, termasuk kesempatan untuk membeli jenis makanan yang beragam (Suyastiri Y.P., 2008).

Selain karakteristik rumah tangga, keragaman konsumsi pangan juga dapat dipengaruhi oleh frekuensi makan (Mekuria dkk, 2017). Akan tetapi, akibat keterbatasan dari data yang tersedia, maka penelitian ini hanya akan membahas faktor sosial demografi dan ekonomi yang berpengaruh terhadap keragaman konsumsi pangan.

Metode riset artikel ini menggunakan data sekunder berupa data mentah hasil dari Survei Sosial Ekonomi Nasional (Susenas) Maret 2018. Wilayah yang menjadi fokus penelitian ini adalah Provinsi Jawa Tengah dengan unit analisis yang diteliti adalah rumah tangga sebanyak 27.294 sampel.

Variabel yang digunakan untuk menganalisis faktor sosial demografi dan ekonomi yang memengaruhi keragaman konsumsi pangan rumah tangga dibagi menjadi dua, yaitu variabel terikat dan variabel bebas. Variabel terikat yang digunakan adalah keragaman konsumsi pangan rumah tangga. Variabel tersebut diukur melalui skor pola pangan harapan (skor PPH). Adapun variabel bebas yang digunakan yaitu umur, jenis kelamin, dan pendidikan kepala rumah tangga, pendapatan perkapita rumah tangga, status daerah tempat tinggal, dan jumlah anggota rumah tangga. Sementara itu, untuk menganalisis hubungan antara keragaman konsumsi pangan dengan tingkat ketahanan pangan di Provinsi Jawa
Tengah, maka variabel bebas yang digunakan adalah keragaman konsumsi pangan yang diukur menggunakan skor $\mathrm{PPH}$, sedangkan variabel terikatnya adalah tingkat ketahanan pangan rumah tangga diukur menggunakan metode klasifikasi Jonsson dan Toole.

Analisis yang digunakan dalam penelitian ini adalah analisis deskriptif dan analisis inferensial berupa analisis regresi logistik biner untuk menganalisis faktor sosial demografi dan ekonomi yang memengaruhi keragaman konsumsi pangan, sedangkan untuk mengkaji apakah terjadi variasi keragaman konsumsi pangan antarwilayah ekskeresidenan digunakan analisis kruskal wallis. Analisis korelasi spearman digunakan dalam penelitian ini untuk mengkaji adanya hubungan antara keragaman konsumsi pangan dan tingkat ketahanan pangan rumah tangga.

\section{PEMBAHASAN \\ Keragaman Konsumsi Pangan di Provinsi Jawa Tengah}

Tingkat keragaman konsumsi pangan dapat diukur dengan beberapa pendekatan, salah satunya adalah skor pola pangan harapan $(\mathrm{PPH})$. Tingkat konsumsi pangan di Provinsi Jawa Tengah tahun 2018 mencapai 89,07 (Tabel 1). Jika merujuk pada kategori skor PPH dari Suhardjo (1998), capaian skor PPH di Provinsi Jawa Tengah tahun 2018 dapat dikatakan sudah cukup baik karena masuk dalam kategori segitiga emas. Kendati demikian, keragaman konsumsi pangan penduduk di Provinsi Jawa Tengah belum dapat mencapai keragaman konsumsi pangan ideal yaitu 100 .

Tabel 1

Pola Pangan Harapan di Provinsi Jawa Tengah

\begin{tabular}{l|l|l|l|l|l|l}
\hline \multicolumn{1}{c|}{ Kelompok Pangan } & Energi (Kkal) & \%AKE & Bobot & Skor AKE & Skor Ideal & Skor PPH \\
\hline Padi-padian & 1264,49 & 58,81 & 0,50 & 29,41 & 25,00 & 25,00 \\
\hline Umbi-umbian & 44,39 & 2,06 & 0,50 & 1,03 & 2,50 & 1,03 \\
\hline Pangan hewani & 212,76 & 9,90 & 2,00 & 19,79 & 24,00 & 19,79 \\
\hline Minyak dan lemak & 226,78 & 10,55 & 0,50 & 5,27 & 5,00 & 5,00 \\
\hline Buah/biji berminyak & 20,12 & 0,94 & 0,50 & 0,47 & 1,00 & 0,47 \\
\hline Kacang-kacangan & 68,25 & 3,17 & 2,00 & 6,35 & 10,00 & 6,35 \\
\hline Gula & 87,14 & 4,05 & 0,50 & 2,03 & 2,50 & 2,03 \\
\hline
\end{tabular}


Lanjutan tabel 1

\begin{tabular}{l|l|l|l|l|l|l}
\hline \multicolumn{1}{c|}{ Kelompok Pangan } & Energi (Kkal) & \%AKE & Bobot & Skor AKE & Skor Ideal & Skor PPH \\
\hline Sayur dan buah & 126,43 & 5,88 & 5,00 & 29,40 & 30,00 & 29,40 \\
\hline Lain-lain & 56,34 & 2,62 & 0,00 & 0,00 & 0,00 & 0,00 \\
\hline Jumlah & & & & & 100 & 89,07 \\
\hline
\end{tabular}

Sumber: Susenas Maret 2018, diolah penulis

Skor kontribusi energi (skor AKE) pada kelompok padi-padian di Provinsi Jawa Tengah telah melampaui skor ideal yaitu 25 . Skor kontribusi energi pada kelompok padipadian penduduk di Provinsi Jawa Tengah telah menyentuh angka 29,41. Kondisi ini sejalan dengan hasil penelitian Rachman \& Ariani (2008) yang menunjukkan bahwa pola konsumsi penduduk telah beralih dari pangan lokal menjadi pola beras dan mi. Ditinjau dari aspek kualitas pangan, konsumsi penduduk Indonesia cenderung masih didominasi pangan sumber karbohidrat, khususnya kelompok padi-padian. Penelitian Suryana (2008) juga mengungkapkan hal serupa bahwa konsumsi pangan yang berasal dari padi-padian sudah melewati standar yang dianjurkan yaitu 50 persen, kenyatannya konsumsi padi-padian penduduk Indonesia mencapai 61,74 persen pada tahun 2017.

Konsumsi minyak dan lemak di Provinsi Jawa Tengah juga telah melewati batas idealnya (Tabel 1). Taruvinga dkk (2013) yang meneliti tentang konsumsi rumah tangga di Distrik Amantole dan Nyandeni, Afrika Selatan menunjukkan bahwa komoditas minyak merupakan salah satu komoditas pangan yang umum dikonsumsi rumah tangga di wilayah tersebut yaitu sebesar 12 persen. Konsumsi minyak lemak yang melebihi standar tersebut dapat disebabkan oleh kebiasaan masyarakat di Indonesia yang gemar menggunakan komoditas minyak beserta olahannya untuk keperluan sehari-hari untuk mengolah bahan pangan.

Kondisi berbeda terjadi pada konsumsi umbi-umbian. Skor PPH kelompok umbiumbian belum mencapai setengah $(1,03)$ dari skor PPH ideal $(2,5)$ (Tabel 1). Hal ini sangat disayangkan mengingat ketersediaan pangan umbi-umbian di Provinsi Jawa Tengah cukup baik. Hal tersebut dapat dilihat dari nilai produksi ubi kayu sebesar 3.138.864 kuintal, sedangkan ubi jalar sebanyak 145.068 kuintal pada tahun 2017 (Badan Pusat Statistik Provinsi Jawa Tengah, 2018).

Pada pangan sumber zat pembangun (protein), konsumsi energi yang berasal dari pangan hewani dan kacang-kacangan juga masih kurang dari skor ideal (Tabel 1). Rendahnya skor PPH juga terjadi pada kelompok pangan sayur dan buah yang berfungsi sebagai zat pengatur dalam tubuh. Penelitian Taruvinga dkk (2013) juga menunjukkan hal serupa bahwa pangan berupa susu, sayur, telur, daging, buah, dan ikan merupakan jenis pangan yang jarang dikonsumsi rumah tangga.

Hal menarik yang bisa dilihat dari kondisi keragaman konsumsi adalah variasi yang terjadi antarwilayah. Secara kewilayahannya, Provinsi Jawa Tengah memiliki histori pembagian wilayah berupa keresidenan. Hal yang menarik dari pembagian wilayah secara keresidenan ini adalah aspek kultur budaya. Kultur budaya yang ada dalam suatu keresidenan biasanya berbeda dengan keresidenan lainnya. Sementara itu, kultur budaya dalam suatu keresidenan biasanya hampir sama, termasuk di dalamnya kebiasaan dalam mengonsumsi makanan di wilayah tersebut sehingga. Pembagian wilayah secara keresidenan di Indonesia memang sudah lama dihapuskan dari sistem ketatanegaraan, tetapi aspek kultur budaya yang sudah terbentuk masih dapat terlihat dalam masyarakat yang tinggal di wilayah tersebut. Provinsi Jawa Tengah sendiri memiliki enam wilayah ekskeresidenan, yaitu ekskeresidenan Semarang, Pekalongan, Surakarta, Pati, Kedu, dan Banyumas. 


\section{Variasi Keragaman Konsumsi Pangan menurut Ekskeresidenan di Provinsi Jawa Tengah}

Jika dilihat berdasarkan wilayah ekskeresidenan, skor PPHyang dicapai oleh seluruh ekskeresidenan di Provinsi Jawa Tengah dapat dikatakan cukup bagus, meskipun belum ada satupun dari keenam ekskeresidenan tersebut mencapai skor ideal (Tabel 2). Tidak ada satupun dari keenam wilayah ekskeresidenan di Provinsi Jawa Tengah dengan skor PPH terkategori segitiga perunggu. Skor PPH untuk wilayah Ekskeresidenan Banyumas dan Kedu termasuk dalam kelompok segitiga perak, sedangkan empat ekskeresidenan lainnya termasuk dalam kelompok segitiga emas.
Ekskeresidenan Semarang mencapai skor $\mathrm{PPH}$ tertinggi dibandingkan dengan wilayah lainnya yakni sebesar 90,20, sedangkan skor $\mathrm{PPH}$ terendah berada di Ekskeresidenan Kedu 85,35. Rendahnya skor PPH di wilayah Ekskeresidenan Kedu kemungkinan disebabkan adanya kemampuan atau daya beli masyarakat di wilayah Ekskeresidenan Kedu yang kurang jika dibandingkan dengan masyarakat di wilayah ekskeresidenan lainnya. Hal tersebut dapat dilihat dari persentase penduduk miskin pada setiap kabupaten/kota yang berada di wilayah Ekskeresidenan Kedu relatif tinggi, terutama Kabupaten Wonosobo dan Kabupaten Kebumen sebagai kabupaten dengan tingkat kemiskinan tertinggi pertama dan kedua di Provinsi Jawa Tengah.

Tabel 2

Skor PPH Provinsi Jawa Tengah menurut wilayah Ekskeresidenan

\begin{tabular}{|c|c|c|c|c|c|c|c|}
\hline \multirow{2}{*}{ Kelompok Pangan } & \multicolumn{6}{|c|}{ Ekskeresidenan } & \multirow{2}{*}{$\begin{array}{l}\text { Skor } \\
\text { Ideal }\end{array}$} \\
\hline & Banyumas & Kedu & Surakarta & Semarang & Pati & Pekalongan & \\
\hline Padi-padian & 25,00 & 25,00 & 25,00 & 25,00 & 25,00 & 25,00 & 25,00 \\
\hline Umbi-umbian & 1,04 & 1,16 & 1,15 & 1,06 & 0,97 & 0,84 & 2,50 \\
\hline Pangan hewani & 17,68 & 15,37 & 19,42 & 22,66 & 20,94 & 21,38 & 24,00 \\
\hline Minyak dan lemak & 5,00 & 5,00 & 5,00 & 5,00 & 5,00 & 4,30 & 5,00 \\
\hline Buah/biji berminyak & 0,39 & 0,68 & 0,47 & 0,43 & 0,51 & 0,37 & 1,00 \\
\hline Kacang-kacangan & 5,92 & 6,30 & 7,06 & 5,73 & 6,30 & 6,68 & 10,00 \\
\hline Gula & 1,84 & 2,42 & 2,50 & 1,90 & 1,73 & 1,76 & 2,50 \\
\hline Sayur dan buah & 30,00 & 29,42 & 28,06 & 28,41 & 27,73 & 29,78 & 30,00 \\
\hline Lain-lain & 0,00 & 0,00 & 0,00 & 0,00 & 0,00 & 0,00 & 0,00 \\
\hline Skor PPH & 86,87 & 85,35 & 88,66 & 90,20 & 88,18 & 90,12 & 100,00 \\
\hline
\end{tabular}

Sumber: Susenas Maret 2018, diolah penulis

Rata-rata konsumsi padi-padian di seluruh wilayah ekskeresidenan Jawa Tengah telah melampaui konsumsi ideal $(25,00)$. Begitu pula dengan konsumsi minyak dan lemak, kecuali di wilayah Ekskeresidenan Pekalongan yakni sebesar 4,30. Konsumsi pangan hewani di Ekskeresidenan Kedu memiliki skor terkecil dibandingkan wilayah lainnya. Hal ini kemungkinan disebabkan adanya keterbatasan akses masyarakat terhadap produk hewani di wilayah tersebut. Produk hewani merupakan komoditi atau kelompok pangan yang bernilai ekonomi yang relatif tinggi dibandingkan komoditas pangan lainnya, sehingga untuk dapat mengakses pangan tersebut dibutuhkan biaya yang lebih tinggi. Konsumsi kacang-kacangan dan buah/biji berminyak masih di bawah standar ideal di seluruh wilayah ekskeresidenan. Konsumsi gula di Ekskeresidenan Surakarta sudah melampaui standar idealnya, kemudian disusul oleh Ekskeresidenan Kedu yang hampir mendekati standar ideal. Konsumsi pangan yang cenderung tinggi pada padi- 
padian, gula, minyak lemak perlu diwaspadai mengingat kelebihan jenis pangan tersebut dapat berdampak kurang baik baik kesehatan.

Guna melihat perbedaan rata-rata keragaman konsumsi di antara wilayah ekskeresidenan di Provinsi Jawa Tengah, maka dilakukan pengujian menggunakan uji kruskalwallis. Hasil uji kruskal-wallis menunjukkan bahwa nilai signifikansi kurang dari 0,05, sehingga dapat disimpulkan bahwa rata-rata skor PPH antara ekskeresidenan yang satu denganlainnyaadalah berbeda. Dengankatalain, terdapat variasi keragaman konsumsi pangan antar wilayah ekskeresidenan di Provinsi Jawa Tengah. Hasil penelitian tersebut sejalan dengan pernyataan dalam penelitian yang dilakukan Tejasari (2003) yang menyebutkan bahwa konsumsi pangan dapat berbeda antarwilayah. Hal tersebut terkait dengan kondisi geografis yang menyebabkan perbedaan ketersediaan pangan di masing-masing wilayah. Selain faktor ketersediaan pangan, perbedaan konsumsi pangan antarwilayah juga dapat disebabkan oleh adanya faktor sosial budaya. Hal tersebut terlihat dari model perilaku konsumsi pangan yang dikembangkan oleh Ermawati dan Sarana (2017) menyebutkan bahwa faktor sosial budaya memiliki peran dalam mengontrol perilaku konsumsi pangan seseorang.

\section{Faktor Sosial Demografi dan Ekonomi yang Memengaruhi Keragaman Konsumsi Pangan Rumah Tangga di Provinsi Jawa Tengah}

Analisis regresi logistik biner digunakan untuk mengetahui faktor sosial demografi dan ekonomi yang berpengaruh terhadap keragaman pangan. Variabel terikat dalam analisis ini adalah tingkat keragaman konsumsi pangan yang digambarkan oleh skor PPH yang dikategorikan menjadi dua, yaitu skor $\mathrm{PPH}<88$ dan skor $\mathrm{PPH} \geq 88$. Pada dasarnya, penentuan kategori ini didasarkan pada penelitian Suhardjo (1998) yang telah dimodifikasi, yaitu kategori segitiga perak dan perunggu digabung menjadi satu kategori, yaitu skor $\mathrm{PPH}<88$. Hal ini dilakukan mengingat rata-rata skor $\mathrm{PPH}$ di Provinsi Jawa Tengah relatif di atas angka 80.
Hasil statistik uji G untuk menganalisis pengaruh secara bersama-sama semua variabel bebas dalam model terhadap variabel terikat menghasilkan nilai signifikansi (sig.) kurang dari nilai $\alpha=0,05$, maka dapat disimpulkan bahwa variabel-variabel bebas dalam model secara bersama-sama signifikan memengaruhi keragaman konsumsi pangan di Provinsi Jawa Tengah tahun 2018. Hasil uji koefisien parameter secara parsial dapat dilihat dari nilai statistik Wald pada masing-masing variabel bebas. Jika probabilitas dari variabel tersebut (sig.) kurang dari nilai $\alpha=0,05$ maka variabel bebas tersebut signifikan memengaruhi keragaman konsumsi pangan. Variabelvariabel tersebut adalah jenis kelamin kepala rumah tangga, umur kepala rumah tangga, pendidikan kepala rumah tangga, jumlah anggota rumah tangga, daerah tempat tinggal, dan pengeluaran perkapita rumah tangga.

Jenis kelamin kepala rumah tangga berpengaruh positif dan signifikan terhadap keragaman konsumsi pangan rumah tangga. Hal ini berarti bahwa keragaman konsumsi pangan pada rumah tangga dengan kepala rumah tangga perempuan memiliki peluang lebih besar memiliki tingkat keragaman konsumsi pangan yang tinggi dibandingkan dengan rumah tangga yang dikepalai oleh seorang laki-laki. Berdasarkan nilai odds ratio sebesar 1,140 berarti kecenderungan rumah tangga dengan kepala rumah tangga perempuan memiliki keragaman konsumsi tinggi adalah sebesar 1,140 kali dibandingkan rumah tangga dengan kepala rumah tangga laki-laki. Hasil penelitian tidak sejalan dengan penelitian Parappurathu dkk (2015) di India Timur, Workicho dkk (2016), Misker, Misker, dan Ayele (2016), dan Mekuria dkk (2017) di Ethiopia, serta Codjoe, Okutu, dan Abu (2016) di Ghana yang menyimpulkan bahwa rumah tangga yang memiliki kepala rumah tangga laki-laki cenderung memiliki keragaman konsumsi pangan yang lebih tinggi dibandingkan dengan rumah tangga dengan kepala rumah tangga perempuan. Akan tetapi, penelitian ini sejalan dengan Taruvinga dkk (2013) membuktikan bahwa rumah tangga dengan kepala rumah tangga perempuan di Provinsi Eastern Cape, Afrika Selatan cenderung memiliki peluang yang lebih tinggi memiliki 
Tabel 3

Hasil Analisis Regresi Logistik Biner

\begin{tabular}{l|c|c|l|l|l|l}
\hline \multicolumn{1}{c|}{ Variabel Bebas } & B & S.E. & Wald & df & Sig. & Exp(B) \\
\hline Pendidikan KRT &,- 014 &, 004 & 11,294 & 1 &, 001 &, 986 \\
\hline Daerah tempat tinggal (perdesaan) &, 118 &, 034 & 12,296 & 1 &, 000 & 1,125 \\
\hline Umur KRT ( $\mathbf{2} 6$ tahun) &, 158 &, 045 & 12,500 & 1 &, 000 & 1,172 \\
\hline Jenis kelamin KRT (perempuan) &, 131 &, 043 & 9,405 & 1 &, 002 & 1,140 \\
\hline Pengeluaran perkapita rumah tangga & & & 2365,121 & 4 &, 000 & \\
\hline Pengeluaran perkapita rumah tangga (kuintil 2) & 1,618 &, 104 & 241,622 & 1 &, 000 & 5,042 \\
\hline Pengeluaran perkapita rumah tangga (kuintil 3) & 2,526 &, 100 & 643,622 & 1 &, 000 & 12,501 \\
\hline Pengeluaran perkapita rumah tangga (kuintil 4) & 3,165 &, 098 & 1033,091 & 1 &, 000 & 23,685 \\
\hline Pengeluaran perkapita rumah tangga (kuintil 2) & 3,637 &, 100 & 1320,797 & 1 &, 000 & 37,969 \\
\hline Jumlah anggota rumah tangga (> 4) &,- 456 &, 044 & 106,116 & 1 &, 000 &, 634 \\
\hline Konstanta & $-3,733$ &, 103 & 1322,424 & 1 &, 000 &, 024 \\
\hline
\end{tabular}

Sumber: Susenas Maret 2018, diolah penulis.

keragaman pangan yang tinggi daripada rumah tangga dengan kepala rumah tangga laki-laki. Hal tersebut disebabkan karena perempuan lebih banyak pengalaman dalam hal kegiatan mengelola urusan konsumsi, terutama konsumsi makanan sehingga perempuan lebih berpengalaman dalam memilih makanan yang baik untuk kesehatan dibandingkan dengan laki-laki.

Variabel umur 65 tahun ke atas memiliki pengaruh positif dan signifikan terhadap keragaman konsumsi pangan rumah tangga. Hal ini berarti bahwa rumah tangga dengan kepala rumah tangga berumur 65 tahun ke atas cenderung memiliki peluang yang lebih besar mengonsumsi pangan yang beragam dibandingkan dengan rumah tangga dengan kepala rumah tangga berumur kurang dari 65 tahun. Berdasarkan nilai odds ratio sebesar 1,172 berarti kecenderungan rumah tangga dengan kepala rumah tangga berumur 65 tahun ke atas memiliki keragaman konsumsi tinggi adalah sebesar 1,172 kali dibandingkan rumah tangga dengan kepala rumah tangga berumur kurang dari 65 tahun. Hal ini dapat disebabkan oleh semakin bertambahnya umur seseorang maka pengalamannya pun turut meningkat, seperti pengalaman tentang dampak makanan yang dikonsumsi bagi tubuh dalam jangka waktu tertentu.

Variabel pendidikan kepala rumah tangga juga berpengaruh terhadap keragaman konsumsi pangan, di mana variabel tersebut berpengaruh negatif dan signifikan. Hal ini berarti bahwa semakin tinggi tingkat pendidikan kepala rumah tangga, maka rumah tangga tersebut cenderung memiliki keragaman konsumsi pangan yang rendah. Hasil penelitian ini berbeda dengan penelitian sebelumnya yang menyimpulkan bahwa pendidikan kepala rumah tangga memiliki pengaruhsignifikan dan positif dalammenentukan keragaman pangan (Hanafi, Asmara, dan Nugroho, 2008; Taruvinga dkk, 2013; Surachman, Kusrini, dan Suyatno, 2013; Parappurathu dkk, 2015; Codjoe, dkk, 2016). Pendidikan menyebabkan seseorang memiliki pilihan yang lebih luas, termasuk dalam penentuan makanan yang akan dikonsumsi. Hal ini mengakibatkan tingkat pendidikan yang dimiliki seseorang tidak selalu selaras dengan pola konsumsi yang dilakukan. Pengetahuan mengenai pentingnya mengonsumsi pangan yang beragam tidak selalu beriringan dengan peningkatan konsumsi pangan yang beragam, manakala seseorang memiliki pilihan untuk mengikuti selera dari makanan yang hendak dikonsumsi.

Jumlah anggota rumah tangga juga berpengaruh negatif dan signifikan memengaruhi keragaman konsumsi pangan rumah tangga. Rumah tangga yang memiliki anggota rumah tangga lebih dari empat orang cenderung memiliki peluang lebih kecil untuk memiliki keragaman konsumsi pangan yang tinggi. Berdasarkan nilai odds ratio sebesar 0,634 
berarti kecenderungan rumah tangga dengan jumlah anggota rumah tangga lebih dari empat orang memiliki keragaman konsumsi tinggi adalah sebesar 0,634 kali dibandingkan rumah tangga dengan anggota rumah tangganya yang berjumlah empat orang atau kurang. Peningkatan jumlah anggota rumah tangga disinyalir menjadi faktor terjadinya peningkatan beban pengeluaran rumah tangga sehingga tanpa adanya peningkatan pendapatan yang berarti dalam rumah tangga, maka alokasi anggaran yang ada cenderung akan dialokasikan untuk pemenuhan kuantitas pangan terlebih dahulu dengan sedikit mengesampingkan variasi dari pangan yang dikonsumsi. Hasil penelitian ini sejalan dengan penelitian sebelumnya yang menunjukkan bahwa jumlah anggota rumah tangga berpengaruh negatif dan signifikan terhadap keragaman konsumsi pangan (energi) (Asmara dkk, 2009; Surachman, Kusrini, dan Suyatno, 2013); Ismiasih dkk, 2013).

Daerah tempat tinggal berpengaruh positif dan signifikan terhadap keragaman konsumsi pangan. Rumah tangga yang tinggal di perdesaan memiliki peluang yang lebih besar terkategori memiliki keragaman konsumsi tinggi dibandingkan dengan rumah tangga yang tinggal di perkotaan. Hasil ini berbeda dengan penelitian sebelumnya yang menunjukkan bahwa keragaman konsumsi pangan rumah tangga di perkotaaan lebih baik daripada di perdesaan (Hamid, dkk, 2013; Workicho dkk, 2016). Hal ini kemungkinan disebabkan oleh rumah tangga di Provinsi Jawa Tengah yang tinggal di perdesaan memiliki hasil pertanian maupun ternak hewan yang digunakan untuk konsumsi rumah tangga sehingga tidak terlalu tergantung dengan ketersediaan pangan di pasar.

Pendapatan perkapita rumah tangga yang didekati dengan variabel pengeluaran memiliki pengaruh positif dan signifikan terhadap tingkat keragaman konsumsi pangan. Rumah tangga yang termasuk dalam kuartil dua hingga lima memiliki peluang yang lebih besar untuk memiliki tingkat keragaman konsumsi yang tinggi dibandingkan dengan rumah tangga yang berada pada kuartil satu. Peningkatan pendapatan memang menjadi faktor yang cukup berpengaruh dalam menentukan tingkat keragaman konsumsi pangan rumah tangga. Hal tersebut dikarenakan peningkatan pendapatan biasanya diikuti dengan peningkatan kemampuan atau daya beli. Peningkatan daya beli tersebut menyebabkan rumah tangga lebih leluasa dalam memilih jenis pangan yang akan dibeli, termasuk konsumsi pangan yang bernilai ekonomi tinggi, seperti pangan hewani, sayur, dan buah. Hasil penelitian ini sejalan dengan penelitian yang dilakukan oleh (Suyastiri Y.P. (2008); dan Surachman, Kusrini, dan Suyatno (2013) yang menyimpulkan bahwa peningkatan pendapatan berpengaruh positif dan signifikan terhadap tingkat keragaman konsumsi pangan rumah tangga.

\section{Hubungan antara Keragaman Konsumsi Pangan dengan Tingkat Ketahanan Pangan di Provinsi Jawa Tengah}

Pengukuran ketahanan pangan dalam penelitian ini pada dasarnya menggunakan metode Jonsson dan Toole yang telah dimodifikasi (1991, dalam D. Maxwell dkk, 2000). Modifikasi metode Jonsson dan Toole dilakukan pada kelompok rentan dan tahan pangan yang digabung menjadi satu kelompok. Berdasarkan hasil penghitungan, persentase rumah tangga di Provinsi Jawa Tengah yang terkategori sebagai rumah tangga tahan pangan sebesar 42,25 persen; rentan/kurang pangan sebesar 48,84 persen; dan rawan pangan sebesar 8,91 persen (Gambar 1).

Ditinjau dari status daerah tempat tinggal, persentase rumah tangga rawan pangan lebih banyak yang tinggal di wilayah perdesaan dibandingkan dengan perkotaan (Gambar 1). Persentase rumah tangga rentan/kurang pangan juga lebih banyak yang berada di wilayah perdesaan dibandingkan perkotaan. Sementara itu, rumah tangga tahan pangan proporsinya lebih besar bertempat tinggal di wilayah perkotaan. Hal ini kemungkinan disebabkan rumah tangga yang tinggal di perkotaan memiliki kondisi ekonomi yang lebih baik sehingga aksesibilitas terhadap pangan lebih besar dibandingkan dengan rumah tangga perdesaan. 


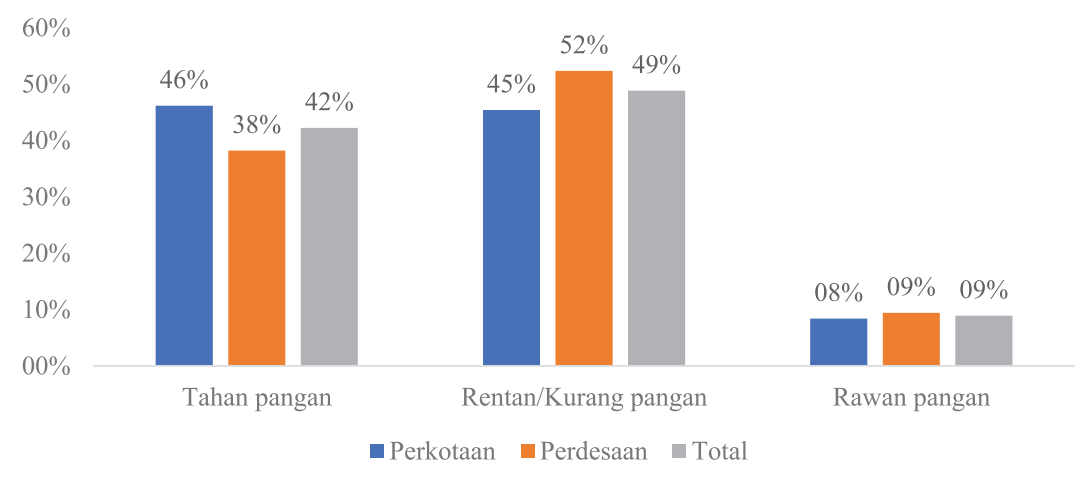

Gambar 1

Persentase Ketahanan Pangan Rumah Tangga Provinsi Jawa Tengah menurut Status Daerah Tempat Tinggal

Sumber: Susenas Maret 2018, diolah penulis.

Ditinjau dari tingkat keragaman konsumsi pangannya, rumah tangga tahan pangan memiliki keragaman konsumsi tinggi (segitiga emas) memiliki proporsi yang paling besar, sedangkan rumah tangga rentan/kurang dan rawan pangan memiliki proporsi terbesar memiliki keragaman konsumsi pangan kurang (segitiga perunggu). Hal ini menunjukkan adanya indikasi bahwa rumah tangga yang memiliki tingkat keragaman konsumsi pangan yang rendah akan cenderung terkategori sebagai rumah tangga rentan/kurang dan rawan pangan, sedangkan rumah tangga yang memiliki keragaman pangan yang tinggi berpeluang lebih besar untuk terkategori sebagai rumah tangga tahan pangan. Hasil penelitian ini sejalan dengan penelitian Ismiasih (2014) menyimpulkan dalam penelitiannya menunjukkan adanya hubungan positif antara keragaman konsumsi pangan dengan tingkat ketahanan pangan rumah tangga. Hasil penelitian ini diperkuat dengan pengujian statistik menggunakan korelasi peringkat spearman yang menghasilkan nilai korelasi sebesar 0,307 dan probabilitas sig.(2-tailed) < 0.05. Hal ini menunjukkan bahwa keragaman konsumsi pangan memiliki hubungan positif dan signifikan dengan tingkat ketahanan pangan rumah tangga atau dengan kata lain, semakin tinggi keragaman konsumsi pangan maka tingkat ketahanan pangannya pun mengalami peningkatan.

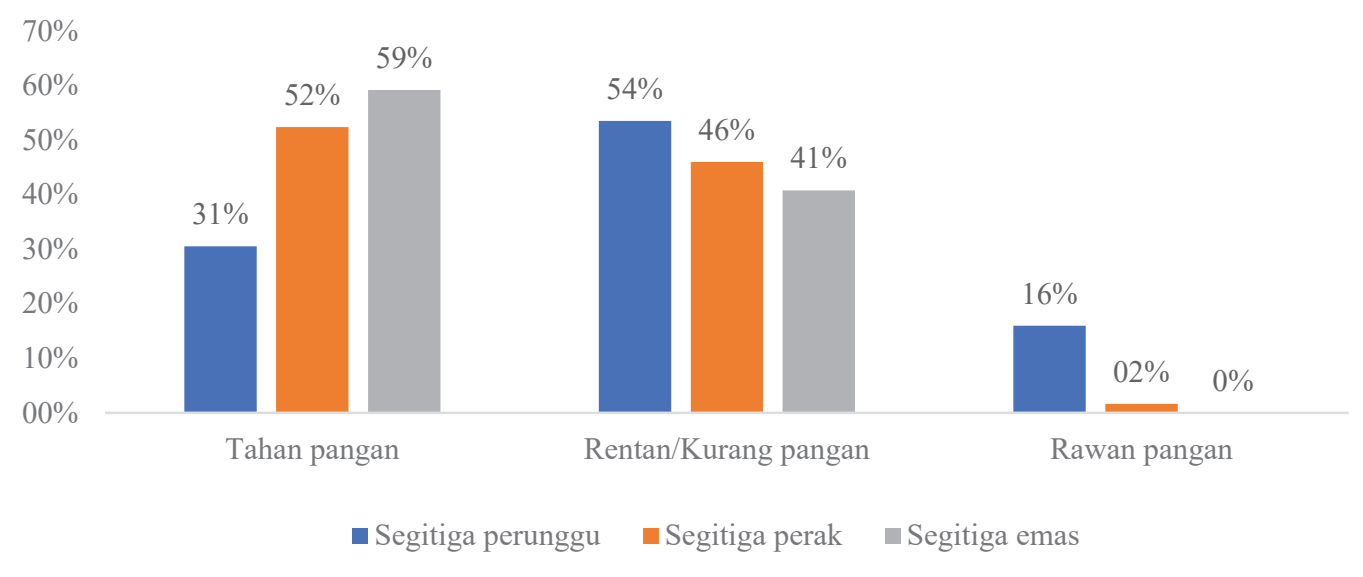

Gambar 2

Persentase Ketahanan Pangan Rumah Tangga Provinsi Jawa Tengah menurut

Tingkat Keragaman Konsumsi Pangan

Sumber: Susenas Maret 2018, diolah penulis. 


\section{SIMPULAN}

Berdasarkan hasil analisis dan pembahasan, maka simpulan dari penelitian ini antara lain kondisi keragaman konsumsi konsumsi pangan di Provinsi Jawa Tengah tahun 2018 sudah cukup baik (terkategori segitiga emas) meskipun belum mencapai kondisi ideal, di mana konsumsi padi-padian dan minyak lemak di Provinsi Jawa Tengah sudah melebihi standar ideal. Selain itu, dilihat variasi antar wilayahnya, terdapat variasi keragaman konsumsi pangan pada keenam wilayah ekskaresidenan di Jawa Tengah.

Variabel sosial demografi dan ekonomi yang memengaruhi keragaman konsumsi pangan rumah tangga adalah jenis kelamin kepala rumah tangga, umur kepala rumah tangga, tingkat pendidikan kepala rumah tangga, jumlah anggota rumah tangga, status daerah tempat tinggal dan pendapatan perkapita rumah tangga. Lebih lanjut, keragaman pangan terbukti memiliki hubungan positif dan signifikan dengan tingkat ketahanan pangan rumah tangga.

Oleh karena itu, keragaman konsumsi pangan tetap perlu ditingkatkan agar tetap dapat mendorong terjaganya ketahanan pangan tingkat rumah tangga. Adapun peningkatan keragaman konsumsi pangan rumah tangga dapat dilakukan dengan mengagendakan secara rutin penyuluhan tentang pangan kepada ibu-ibu rumah tangga, misalnya disisipkan dengan agenda rutin pertemuan seperti Pemberdayaan Kesejahteraan Keluarga (PKK). Selain itu, upaya lainnya yang dapat dilakukan adalah mengagendakan kegiatan pelatihan berupa berkebun dan beternak agar rumah tangga yang memiliki keterbatasan daya beli tetap dapat mengonsumsi pangan yang bergizi dan beragam dari hasil pertanian dan budidaya yang telah dilakukan atau bahkan hasilnya dapat dijual sehingga pendapatan rumah tangga sehingga terjadi perbaikan ekonomi rumah tangga.

\section{Ucapan Terima Kasih}

Riset untuk artikel ini dibiayai oleh APBN Badan Pusat Statistik (BPS). Penulis mengucapkan terima kasih kepada pimpinan
BPS dan Pusdiklat yang memberikan kesempatan untuk mengikuti pendidikan program pascasarjana. Terima kasih untuk semua dosen pengajar dan dosen pembimbing di Prodi Magister Studi Kependudukan Sekolah Pascasarjana UGM serta kepada para reviewer yang telah memberikan masukan untuk perbaikan artikel ini.

\section{DAFTAR PUSTAKA}

Asmara, R., Hanani, N. and Purwaningsih, I. A. (2009) 'Pengaruh faktor ekonomi dan non ekonomi terhadap diversifikasi pangan berdasarkan Pola Pangan Harapan (Studi kasus di Dusun Klagen, Kepuh Kembang, Kecamatan Peterongan, Kabupaten Jombang)', Agrise, IX(1), pp. 19-31.

Badan Ketahanan Pangan (2018) Statistik ketahanan pangan 2017. Jakarta: Badan Ketahanan Pangan.

Badan Pusat Statistik Provinsi Jawa Tengah (2018) Provinsi Jawa Tengah dalam angka. Semarang: Badan Pusat Statistik Provinsi Jawa Tengah.

Codjoe, S. N. A., Okutu, D. and Abu, M. (2016) 'Urban household characteristics and dietary diversity', Food and Nutrition Bulletin, 37(2), pp. 202-218. doi: 10.1177/0379572116631882.

Dewan Ketahanan Pangan, Kementerian Pertanian and World Food Programme (2015) Peta ketahanan dan kerentanan pangan Indonesia 2015. Jakarta: Dewan Ketahanan Pangan, Kementerian Pertanian, dan World Food Programme (WFP).

Ermawati, T. and Sarana, J. (2017) 'Determinan perilaku konsumsi pangan masyarakat di Daerah Istimewa Yogyakarta (DIY) dan Nusa Tenggara Timur (NTT)', Jurnal Ekonomi dan Pembangunan, 25(2), pp. 69-87.

FAO (2010) Guidelines for measuring household and individual dietary diversity, Nutrition and Consumer Protection 
Division. Rome: Food and Agriculture Organization of the United Nations. Available at: http://www.fao. org/3/a-i1983e.pdf.

Hamid, Y., Setiawan, B. and Suhartini (2013) 'Analisis pola konsumsi pangan rumah tangga (Studi kasus di Kecamatan Tarakan Barat Kota Tarakan Provinsi Kalimantan Timur)', Agrise, 13(3), pp. 175-190.

Hanafi, N., Asmara, R. and Nugroho, Y. (2008) 'Analisis diversifikasi konsumsi pangan dalam memantapkan ketahanan pangan masyarakat pedesaan', Agrise, VIII(1), pp. 46-54.

Headey, D. and Ecker, O. (2013) 'Rethinking the measurement of food security: from first principles to best practice', Food Security, 5(3), pp. 327-343. doi: 10.1007/s12571-013-0253-0.

Hoddinott, J. and Yohannes, Y. (2002) Dietary diversity as a household food security. Washington, D.C.: FHI 360/Food and Nutrition Technical Assistance Project (FANTA).

Ismiasih et al. (2013) 'Diversifikasi konsumsi pangan pada tingkat rumah tangga di Provinsi Daerah Istimewa Yogyakarta (Indeks entropi didekati dengan pangsa pangan)', Jurnal Budidaya Pertanian, 9(2), pp. 72-78.

Ismiasih (2014) Konsumsi, diversifikasi dan ketahanan pangan tingkat rumah tangga di Daerah Istimewa Yogyakarta. Universitas Gadjah Mada.

Labadarios, D., Steyn, N. P. and Nel, J. (2011) 'How diverse is the diet of adult South Africans?', Nutrition Journal, 10(1), p. 33. doi: 10.1186/1475-289110-33.

Maxwell, D. et al. (2000) Urban livelihoods and food and nutrition security in Greater Accra, Ghana. Washington, D.C., USA: International Food Policy Research Institute (IFPRI).
Mekuria, G., Wubneh, Y. and Tewabe, T. (2017) 'Household dietary diversity and associated factors among residents of finote selam town, north west Ethiopia: a cross sectional study', BMC Nutrition. BMC Nutrition, 3(1), p. 28. doi: 10.1186/ s40795-017-0148-0.

Michaelsen, K. F. et al. (2009) 'Choice of foods and ingredients for moderately malnourished children 6 months to 5 years of age', Food and Nutrition Bulletin, 30(3), pp. S343-S404. doi: 10.1177/15648265090303S303.

Misker, D., Misker, B. and Ayele, G. (2016) 'House hold dietary diversity and associated factors in Mirab Abaya wereda Southern Ethiopia 2016; community based cross sectional study', Diversity \& Equality in Health $\mathcal{E}$ Care, 13(4), pp. 293-296. Available at: http://ezproxy.bangor.ac.uk/ login?url=http:/ / search.ebscohost. com $/$ login. asp $x$ ?direct $=$ true $\& d b=c 8$ h\&AN=117777321\&site=ehost-live.

Parappurathu, S. et al. (2015) 'Food consumption patterns and dietary diversity in eastern India: evidence from village level studies (VLS)', Food Security, 7(5), pp. 1031-1042. doi: 10.1007/s12571-015-0493-2.

Rachman, H. P. . and Ariani, M. (2008) 'Penganekaragaman konsumsi pangan di Indonesia: Permasalahan dan implikasi untuk kebijakan dan program', Analisis Kebijakan Pertanian, 6(2), pp. 140-154. doi: 10.21082/akp.v6n2.2008.140-154.

Ruel, M. T. (2003a) 'Is dietary diversity an indicator of food security or dietary quality? A review of measurement issues and research needs', Food and Nutrition Bulletin, 24(2), pp. 231-232. doi: $10.1177 / 156482650302400217$.

Ruel, M. T. (2003b) 'Operationalizing dietary diversity: A review of measurement issues and research priorities', 
The Journal of Nutrition, 133(11), p. 3911S-3926S. doi: 10.1093/ jn/133.11.3911S.

Sharma, A. and Chandrasekhar, S. (2016) 'Impact of commuting by workers on household dietary diversity in rural India', Food Policy. Elsevier Ltd, 59, pp. 34-43. doi: 10.1016/j. foodpol.2015.11.005.

Suhardjo (1998) 'Konsep dan kebijaksanaan diverifikasi konsumsi pangan dalam rangka ketahanan pangan', in Winarno, F. . et al. (eds) Widyakarya Nasional Pangan dan Gizi VI. Jakarta: Lembaga Ilmu Pengetahuan Indonesia, pp. 693-714.

Surachman, Kusrini, N. and Suyatno, A. (2013) 'Social-economic factors effecting the diversity of dietary consumption in the self sufficient dietary village of Kubu Raya District', Jurnal Social Economic of Agriculture, 2(2), pp. 1-20.

Suryana, A. (2008) 'Penganekaragaman konsumsi pangan dan gizi: Faktor pendukung peningkatan kualitas sumber daya masyarakat', Pangan, 17(52), pp. 3-12.

Suyastiri Y.P., N. M. (2008) 'Diversifikasi konsumsi pangan pokok berbaasis potensi lokal dalam mewujudkan ketahanan pangan rumahtangga pedesaan di Kecamatan Semin Kabupaten Gunung Kidul', Jurnal Ekonomi Pembangunan, 13(1), pp. 5160.

Taruvinga, A., Muchenje, V. and Mushunje, A. (2013) 'Determinants of rural household dietary diversity: The case of Amatole and Nyandeni districts, South Africa', International Journal of Development and Sustainability, 2(4), pp. 2233-2247. doi: IJDS13060305.

Tejasari (2003) 'Diversifikasi konsumsi pangan berdasarkan pendekatan pola pangan harapan (PPH) di daerah rawan gizi', Media Gizi dan Keluarga, 27(1), pp. 46-53.

Thorne-Lyman, A. L. et al. (2010) ‘Household Dietary Diversity and Food Expenditures Are Closely Linked in Rural Bangladesh, Increasing the Risk of Malnutrition Due to the Financial Crisis', The Journal of Nutrition, 140(1), p. 182S-188S. doi: 10.3945/jn.109.110809.

Workicho, A. et al. (2016) ‘Household dietary diversity and Animal Source Food consumption in Ethiopia: Evidence from the 2011 Welfare Monitoring Survey' , BMC Public Health, 16(1192), pp. 1-12. doi: 10.1186/s12889-0163861-8. 